\title{
Potensi penggunaan limbah ikan leubiem (Chanthidermis maculatus) sebagai sumber protein dalam ransum terhadap produktivitas itik petelur
}

\author{
Muhammad Daud *, M. Aman Yaman, Zulfan \\ Program Studi Peternakan, Fakultas Pertanian, Universitas Syiah Kuala, Banda Aceh, 23111 \\ *Correspondence: daewood@unsyiah.ac.id
}

Received: December 31 $1^{\text {th }}, 2019$; Accepted: June 29th 2020; Published online: November 26 $6^{\text {th }}, 2020$

Abstrak

Tujuan: Penelitian bertujuan untuk mengkaji potensi penggunaan limbah ikan leubiem (Chanthidermis maculatus) sebagai sumber protein dalam formulasi ransum terhadap produktivitas itik petelur. Limbah ikan leubiem yang digunakan adalah: tepung kulit, tulang, kepala dan insang yang diformulasikan dalam ransum basal itik petelur.

Metode: Metode penelitian dilakukan secara eksperimental, menggunakan Rancangan Acak Lengkap (RAL) yang terdiri atas 5 perlakuan ransum dan 4 kali ulangan. Perlakuan ransum yang digunakan adalah: R0 (ransum basal kontrol/tanpa limbah ikan leubiem), R1 (ransum basal mengandung $10 \%$ tepung kulit ikan leubiem), R2 (ransum basal mengandung $10 \%$ tepung kepala ikan leubiem), R3 (ransum basal mengandung 10\% tepung tulang ikan leubiem) dan R4 (ransum basal mengandung $10 \%$ tepung insang ikan leubiem). Variabel yang diamati yaitu: konsumsi ransum, bobot badan pertama bertelur, pertambahan bobot badan, umur pertama bertelur, bobot telur pertama, produksi telur, konversi ransum, bobot badan akhir dan indeks bentuk telur. Data yang diperoleh dianalisis dengan Analysis of Variance (ANOVA) dan dilanjutkan dengan uji jarak berganda Duncan.

Hasil: Hasil penelitian menunjukkan bahwa penggunaan limbah ikan leubiem dalam ransum memberi pengaruh yang signifikan $(p<0,05)$ terhadap konsumsi ransum, bobot badan pertama bertelur, pertambahan bobot badan, produksi telur, konversi ransum, dan bobot badan akhir, namun tidak berpengaruh nyata terhadap umur pertama bertelur, bobot telur pertama dan indeks bentuk telur.

Kesimpulan: Kesimpulan penelitian adalah penggunaan limbah ikan leubiem (kulit, kepala, tulang dan insang) dalam formulasi ransum tidak memberi efek negatif terhadap produktivitas itik petelur, dan sangat berpotensi digunakan sebagai salah satu bahan penyusun ransum sumber protein dalam formulasi ransum itik petelur umur 21-29 minggu.

Kata Kunci: Itik petelur; Limbah ikan; Ransum; Protein

Abstract

Objective: This research aimed to examine the potential use of leubiem fish waste (Chanthidermis maculatus) as a protein source in ration formulations on laying ducks productivity. The waste used (skin, bones, head and gills) was formulated in basal rations. 
Methods: The method was experimental, using a Completely Randomized Design (CRD) consisting of 5 ration treatments and 4 replications. The treatments used were R0 (control basal ration / without leubiem fish waste), R1 (containing 10\% leubiem fish skin flour), R2 (containing 10\% head flour), R3 (containing 10\% bone flour), and R4 (containing 10\% fish gill flour). The observed variables were consumption, body weight at first laying, body weight gain, first age at laying, first egg weight, daily egg production, ration conversion, final body weight and egg shape index. Data was analyzed using the Analysis of Variance (ANOVA), and continued with Duncan's multiple range tests.

Results: The results showed the use of leubiem fish waste in ration had a significant effect $(p<0.05)$ on consumption, body weight at first laying, weight gain, daily egg production, ration conversion, and final body weight, but had no effect on the first laying age, first egg weight and shape index.

Conclusions: Therefore, it can be concluded that the use of leubiem fish waste (skin, head, bones and gills) in ration formulation does not have a negative effect on productivity, and can be potentially used as an ingredient of protein source rations for laying ducks aged 21-29 weeks.

Keywords: Ducks; Fish waste; Ration; Protein

\section{PENDAHULUAN}

Persoalan pakan masih menjadi salah satu isu pokok dalam kegiatan usaha peternakan, khususnya usaha ternak unggas. Hal ini terutama karena pakan merupakan komponen yang signifikan dalam struktur biaya produksi ternak. Selain faktor biaya, kandungan dan komposisi nutrisi pakan juga akan berpengaruh langsung terhadap kesehatan ternak. Kesehatan ternak secara langsung juga akan memengaruhi produktivitas ternak [1]. Kecukupan pakan, dalam hal jumlah dan kualitasnya merupakan persyaratan yang harus dipenuhi untuk menjamin agar ternak sehat, tumbuh normal dan berproduksi secara optimal. Ketergantungan pada pakan komersil dalam jumlah besar akan menjadi masalah bagi usaha peternakan itik, khususnya usaha itik petelur karena tingginya biaya produksi yang dikeluarkan, sehingga perlu diintensifkan upaya eksplorasi bahan baku pakan lokal dengan tetap memperhatikan kualitas, kandungan nutrisi, tersedia dalam jumlah memadai, dan terjangkau harganya oleh peternak.

Upaya untuk mengatasi permasalahan tersebut yaitu dengan mencari dan menyediakan bahan baku pakan alternatif yang murah, mudah didapat serta penggunaannya tidak bersaing dengan kebutuhan manusia. Salah satu bahan pakan alternatif tersebut yang berpotensi digunakan dalam formulasi ransum itik petelur adalah limbah ikan. Limbah ikan adalah sisa dari pemotongan ikan di pasar ikan maupun hasil sampingan dari industri pengolahan ikan baik skala kecil, menengah maupun besar. Limbah ikan dapat berupa limbah cair maupun limbah padat. Limbah cair berupa air cucian dari pengolahan ikan, sedangkan limbah padat berupa tulang, daging, kepala, kulit, sisik, jeroan dan bahkan ikan hasil tangkapan dapat menjadi limbah [2].

Limbah ikan jika tidak dikelola dengan baik akan menimbulkan pencemaran karena proses pembusukan protein ikan. Selain itu bisa menjadi sumber penyakit menular pada manusia yang ditularkan oleh lalat sebagai perantara (misalnya muntaber). Limbah ikan yang dijadikan sebagai bahan baku pakan penyusun ransum itik petelur dalam penelitian ini adalah limbah ikan leubiem. Limbah ikan leubiem merupakan sisa hasil pemotongan ikan berupa kepala, kulit atau sisik, tulang, insang dan termasuk juga bagian jeroan. Limbah ikan leubiem diolah menjadi tepung dengan cara dijemur pada sinar matahari selanjutnya digrinder dengan menggunakan hammer milk sehingga menjadi tepung limbah ikan leubiem. Pengolahan limbah ikan secara terencana dapat memberi keuntungan ganda berupa pemanfaatan limbah ikan sebagai sumber protein khususnya sebagai komponen penyusun ransum itik petelur serta dapat mengurangi pencemaran lingkungan.

Ikan leubiem memiliki kandungan nutrisi yang cukup baik salah satunya adalah memiliki kandungan protein yang cukup tinggi. Kandungan protein kasar limbah ikan 
leubiem berkisar antara 47,90 - 64,09\% (Tabel 1). Kadar protein kasar yang terdapat pada limbah ikan leubiem berpotensi digunakan sebagai sumber protein dalam formulasi ransum guna meningkatkan pertumbuhan atau produktivitas itik petelur. Beberapa hasil penelitian sebelumnya menunjukkan bahwa penggunaan limbah ikan leubiem (Chanthidermis maculatus) sebagai bahan pakan dalam formulasi ransum itik lokal dapat memberi respon positif terhadap performan dan persentase karkas itik lokal jantan umur 16 minggu, serta meningkatkan kinerja pertumbuhan itik lokal umur 8-20 minggu $[3,4]$.

Upaya meningkatkan produktivitas itik petelur dan mencari serta menyediakan bahan pakan alternatif semestinya selalu dilakukan. Salah satunya adalah dengan pemberian pakan yang seimbang dan sesuai dengan kebutuhan nutrisi itik petelur serta pemanfaatan limbah atau by product seperti limbah ikan leubiem sebagai sumber protein dalam formulasi ransum. Keseimbangan dan kebutuhan nutrisi sangat diperlukan dalam menyusun formulasi ransum itik petelur guna memacu pertumbuhan atau meningkatkan produktivitas dan efisiensi pakan. Berbagai upaya tersebut merupakan dasar perlunya penelitian tentang potensi penggunaan limbah ikan leubiem dalam formulasi ransum sehingga menambah nilai guna limbah ikan leubiem sebagai bahan pakan sumber protein yang berguna untuk memacu pertumbuhan dan meningkatkan produktivitas itik petelur.

Tujuan penelitian adalah untuk mengkaji potensi penggunaan limbah ikan leubiem (tepung kulit, insang, kepala dan tulang) sebagai sumber protein dalam formulasi ransum dan pengaruhnya terhadap produktivitas itik petelur.

\section{MATERI DAN METODE}

Materi penelitian yang digunakan adalah itik petelur (itik Alabio) umur 21 minggu sejumlah 100 ekor yang dipelihara hingga berumur 29 minggu pada kandang postal/litter sebanyak 20 unit dengan ukuran masing-masing unit kandang $1 \times 1$ meter dan dilapisi dengan alas sekam padi setebal \pm 10 $\mathrm{cm}$. Setiap unit kandang terdiri atas 5 ekor itik petelur. Bahan pakan yang digunakan terdiri atas: limbah ikan leubiem (tepung kulit, kepala, tulang dan insang), jagung, dedak padi, bungkil kelapa, bungkil kedelai, ampas sagu, minyak kelapa, premix, garam, dan mineral bebek. Peralatan yang digunakan yaitu kandang sekat, litter, kawat sekat pembatas kandang, lampu pijar, tempat makan, tempat minum, timbangan, ember, dan perlengkapan kandang lainnya.

\section{Metode Penelitian}

Penelitian dilakukan dengan metode eksperimental, menggunakan Rancangan Acak Lengkap (RAL) dengan 5 perlakuan ransum dan 4 ulangan (5 ekor itik/ulangan). Perlakuan ransum terdiri atas: R0 (ransum basal kontrol/tanpa limbah ikan leubiem), R1 (ransum basal mengandung 10\% tepung kulit ikan leubiem), R2 (ransum basal mengandung $10 \%$ tepung kepala ikan leubiem), R3 (ransum basal mengandung $10 \%$ tepung tulang ikan leubiem) dan R4 (ransum basal mengandung $10 \%$ tepung insang ikan leubiem).

Tabel 1. Kandungan nutrisi limbah ikan leubiem (Chanthidermis maculatus)

\begin{tabular}{lcccc}
\hline \multirow{2}{*}{$\begin{array}{c}\text { Kandungan } \\
\text { nutrisi (\%) }\end{array}$} & $\begin{array}{c}\text { Tepung kulit } \\
\text { ikan leubiem }\end{array}$ & $\begin{array}{c}\text { Tepung kepala } \\
\text { ikan leubiem }\end{array}$ & $\begin{array}{c}\text { Tepung tulang } \\
\text { ikan leubiem }\end{array}$ & $\begin{array}{c}\text { Tepung insang } \\
\text { ikan leubiem }\end{array}$ \\
\cline { 2 - 5 } Kadar air & 8,90 & 12,48 & 10,12 & 11,06 \\
Kadar abu & 43,89 & 30,61 & 22,40 & 17,63 \\
Protein kasar & 47,90 & 54,03 & 64,09 & 62,05 \\
Lemak kasar & 0,46 & 1,57 & 2,45 & 3,40 \\
Serat kasar & 0,56 & 0,70 & 0,68 & 0,00 \\
Calsium & 14.50 & 9.33 & 7.12 & 4.70 \\
Fosfor & 7,44 & 5,29 & 3,94 & 2,45 \\
\hline
\end{tabular}


Semua ransum perlakuan menggunakan bahan pakan yang sama, hanya berbeda pada penggunaan tepung limbah ikan leubiem. Ransum yang digunakan diformulasikan sesuai dengan kebutuhan nutrisi itik petelur fase layer yaitu kandungan protein kasar $17 \%$ dan energi metabolisme $2700 \mathrm{kkal} / \mathrm{kg}$ [5]. Susunan bahan pakan dan kandungan nutrisi masing-masing ransum perlakuan ditampilkan pada Tabel 2.

\section{Variabel Penelitian}

Variabel yang diamati meliputi: performan (konsumsi ransum, pertambahan bobot badan, bobot badan bertelur pertama, konversi ransum, dan bobot badan akhir), dan produksi telur fase pertama (umur bertelur pertama, bobot telur pertama, produksi telur, dan indeks bentuk telur) yang diperoleh dari hasil pengamatan dan pengumpulan data kemudian ditabulasi dan selanjutnya data dianalisis melalui pendekatan berikut:
1. Konsumsi ransum, diperoleh dari rata-rata jumlah pemberian ransum dikurangi jumlah ransum yang tersisa (g/ekor/hari).

2. Pertambahan bobot badan (PBB), diperoleh dengan menimbang berat badan akhir dikurangi dengan berat awal itik petelur (g/ekor).

3. Bobot badan bertelur pertama, diperoleh dengan melakukan penimbangan itik petelur pada saat pertama bertelur dengan menggunakan timbangan digital (g/ekor).

4. Konversi ransum, diperoleh dari perbandingan jumlah konsumsi ransum dengan bobot akhir itik petelur pada periode penelitian.

5. Bobot badan akhir diperoleh dari hasil penimbangan bobot badan itik petelur pada akhir periode penelitian (g/ekor).

6. Umur bertelur pertama, diperoleh dari hasil pengamatan pada waktu pertama itik mulai bertelur.

Tabel 2. Komposisi dan kandungan nutrisi ransum itik petelur umur 21-29 minggu

\begin{tabular}{lrrrrr}
\hline \multirow{2}{*}{ Bahan pakan (\%) } & \multicolumn{5}{c}{ Perlakuan ransum } \\
\cline { 2 - 6 } & $\mathrm{R} 0$ (\%) & $\mathrm{R} 1(\%)$ & $\mathrm{R} 2(\%)$ & $\mathrm{R} 3(\%)$ & $\mathrm{R} 4(\%)$ \\
\hline Dedak jagung & 45,0 & 40,0 & 39,0 & 38,0 & 39,0 \\
Dedak padi & 12,0 & 18,0 & 18,0 & 18,0 & 18,0 \\
Bungkil kelapa & 11,0 & 12,0 & 13,0 & 13,0 & 12,0 \\
Bungkil kacang kedelai & 24,0 & 8,0 & 8,0 & 9,0 & 9,0 \\
Ampas Sagu & 5,0 & 9,0 & 9,0 & 9,0 & 9,1 \\
Tepung kulit ikan leubiem & 0,0 & $\mathbf{1 0 , 0}$ & 0,0 & 0,0 & 0,0 \\
Tepung kepala ikan leubiem & 0,0 & 0,0 & $\mathbf{1 0 , 0}$ & 0,0 & 0,0 \\
Tepung tulang ikan leubiem & 0,0 & 0,0 & 0,0 & $\mathbf{1 0 , 0}$ & 0,0 \\
Tepung insang ikan leubiem & 0,0 & 0,0 & 0,0 & 0,0 & $\mathbf{1 0 , 0}$ \\
Minyak kelapa & 1,5 & 1,5 & 1,5 & 1,5 & 1,5 \\
Premix & 0,5 & 0,5 & 0,5 & 0,5 & 0,5 \\
Garam & 0,5 & 0,5 & 0,5 & 0,5 & 0,5 \\
Mineral bebek & 0,5 & 0,5 & 0,5 & 0,5 & 0,5 \\
\hline Jumlah & 100,0 & 100,0 & 100,0 & 100,0 & 100,0 \\
\hline Kandungan nutrisi: & \multicolumn{5}{c}{} \\
\hline Energi metabolisme (Kkal/kg) & 2.706 & 2.726 & 2.708 & 2.700 & 2.716 \\
Protein kasar (\%) & 17,15 & 17,05 & 17,17 & 17,52 & 17,35 \\
Serat kasar (\%) & 5,38 & 6,16 & 6,28 & 6,28 & 6,17 \\
Lemak kasar (\%) & 2,90 & 3,34 & 3,32 & 3,29 & 3,31 \\
Calsium (\%) & 0,80 & 1,47 & 1,42 & 1,43 & 1,42 \\
Fosfor (\%) & 0,57 & 0,87 & 0,87 & 0,88 & 0,87 \\
\hline
\end{tabular}


7. Bobot telur pertama, diperoleh dengan melakukan penimbangan telur menggunakan timbangan digital (g/butir).

8. Produksi telur, diperoleh dari perbandingan jumlah telur yang dihasilkan perminggu (butir) dengan jumlah itik petelur yang hidup pada setiap minggu (ekor) dikalikan $100 \%$.

9. Indeks bentuk telur, diperoleh dari hasil pengukuran panjang dan lebar telur dikali 100 atau dengan rumus berikut:

Indeks bentuk telur $=\frac{\text { lebar telur }}{\text { panjang telur }} \times 100$

\section{Analisis data}

Data yang diperoleh dianalisis dengan Analysis of Variance (ANOVA) menggunakan aplikasi SPSS Statistics 20.0 untuk melihat perbedaan antar perlakuan. Apabila terdapat perbedaan yang nyata diantara perlakuan maka dilanjutkan dengan uji jarak berganda Duncan [6].

\section{HASIL DAN PEMBAHASAN}

\section{Performan itik petelur}

Hasil penelitian menunjukkan bahwa pemberian ransum yang mengandung tepung limbah ikan leubiem berpengaruh nyata $(\mathrm{p}<0,05)$ terhadap performan itik petelur umur 21-29 minggu. Berdasarkan hasil analisis statistik menunjukkan bahwa penggunaan limbah ikan leubiem (tepung kulit, kepala, tulang dan insang) dalam formulasi ransum itik petelur berpengaruh nyata $(\mathrm{p}<0,05)$ terhadap konsumsi ransum. Konsumsi ransum tertinggi diperoleh pada perlakuan ransum yang mengandung tepung kulit ikan leubiem (R1) yaitu 197,94 g/ekor/hari dan lebih tinggi $(\mathrm{p}<0,05)$ dibandingkan dengan perlakuan ransum kontrol (R0) yaitu 159,83 g/ekor/hari serta perlakuan ransum yang mengandung tepung insang (R4) yaitu 158,38 g/ekor/hari, namun tidak berbeda nyata dengan perlakuan ransum yang mengandung tepung kepala dan tulang ikan leubiem (R2 dan R3) yaitu 192,94 dan 191,66 g/ekor/hari (Tabel 3).

Konsumsi ransum berkorelasi dengan pertambahan bobot badan itik petelur, dimana penggunaan tepung limbah ikan leubiem dalam formulasi ransum memberi pengaruh yang signifikan $(p<0,05)$ terhadap pertambahan bobot badan itik petelur umur 21 - 29 minggu (Tabel 3). Pertambahan bobot badan tertinggi diperoleh pada perlakuan ransum yang mengandung tepung kulit ikan leubiem (R1) yaitu 89,90 g/ekor/minggu, dan lebih tinggi $(\mathrm{p}<0,05)$ dibandingkan dengan perlakuan ransum kontrol (R0) serta perlakuan ransum yang mengandung tepung insang ikan leubiem (R4), namun tidak berbeda nyata bila dibandingkan dengan perlakuan ransum yang mengandung tepung kepala dan tulang ikan leubiem (R2 dan R3).

Hasil penelitian menunjukkan bahwa pertambahan bobot badan itik petelur yang diberi ransum mengandung limbah ikan leubiem (tepung kulit, kepala dan tulang) lebih baik bila dibandingkan dengan pemberian

Tabel 3. Performan itik petelur umur 21-29 minggu

\begin{tabular}{lcrrrr}
\hline \multirow{2}{*}{ Variabel } & \multicolumn{5}{c}{ Perlakuan Ransum } \\
\cline { 2 - 6 } & R0 & R1 & R2 & R3 & R4 \\
\hline $\begin{array}{l}\text { Konsumsi ransum } \\
\text { (g/ekor/hari) }\end{array}$ & $159,83 \pm 19,16^{\mathrm{a}}$ & $197,94 \pm 2,08^{\mathrm{b}}$ & $192,94 \pm 3,95^{\mathrm{ab}}$ & $191,66 \pm 3,61^{\mathrm{ab}}$ & $158,38 \pm 34,35^{\mathrm{a}}$ \\
Pertambahan berat & $81,56 \pm 2,8^{\mathrm{a}}$ & $89,90 \pm 2,2^{\mathrm{b}}$ & $87,58 \pm 2,6^{\mathrm{b}}$ & $85,26 \pm 2,2^{\mathrm{b}}$ & $79,71 \pm 2,9^{\mathrm{a}}$ \\
badan (g/ekor/minggu) & & & & & \\
Konversi ransum & $3,56 \pm 1,9^{\mathrm{b}}$ & $3,36 \pm 0,15^{\mathrm{b}}$ & $3,15 \pm 1,19^{\mathrm{a}}$ & $3,19 \pm 1,13^{\mathrm{a}}$ & $3,09 \pm 1,24^{\mathrm{a}}$ \\
$\begin{array}{l}\text { Bobot badan akhir } \\
\text { (g/ekor) }\end{array}$ & $2.228 \pm 23,4^{\mathrm{a}}$ & $2.309 \pm 73,6^{\mathrm{b}}$ & $2.303 \pm 77,6^{\mathrm{b}}$ & $2.297 \pm 65,7^{\mathrm{b}}$ & $2.257 \pm 20,4^{\mathrm{a}}$ \\
\hline
\end{tabular}

Keterangan : ${ }^{a, b, c}$ superskrip yang berbeda pada baris yang sama menunjukkan perbedaan yang nyata $(\mathrm{p}<0,05)$; R0 = ransum kontrol (tanpa limbah ikan leubiem); R1 = ransum basal mengandung 10\% kulit ikan leubiem; R2 = ransum basal mengandung 10\% kepala ikan leubiem; R3 = ransum basal mengandung 10\% tulang ikan leubiem; R4 = ransum basal mengandung 10\% insang ikan leubiem 
ransum kontrol (R0) dan ransum yang mengandung tepung insang. Rataan pertambahan bobot badan itik petelur yang dicapai dengan pemberian ransum yang mengandung limbah ikan leubiem (tepung kulit, kepala dan tulang) masing-masing adalah sebesar 89,90, 87,58, dan 85,26 g/ekor/minggu, sedangkan pertambahan berat badan itik petelur yang diberi ransum mengandung tepung insang dan ransum kontrol lebih rendah yaitu 79,71 dan 81,56 g/ekor/minggu (Tabel 3).

Demikian juga terhadap nilai konversi ransum, pemberian ransum yang mengandung limbah ikan leubiem memberi pengaruh yang nyata $(\mathrm{p}<0,05)$ diantara perlakuan ransum. Hal ini sesuai dengan data konsumsi ransum sebelumnya menunjukkan perbedaan yang nyata diantara perlakuan. Nilai konversi ransum terendah terdapat pada perlakuan ransum yang mengandung tepung kepala ikan leubiem (R2) yaitu 3,15 dan nilai konversi ransum tertinggi diperoleh pada perlakuan ransum kontrol (R0) yaitu 3,56 (Tabel 3). Hal ini memberi indikasi bahwa ransum yang mengandung tepung limbah ikan leubiem dalam formulasi ransum itik petelur merupakan ransum yang paling efisien untuk mencapai bobot badan itik petelur yang maksimal dan lebih baik dibandingkan dengan ransum kontrol (tanpa limbah ikan leubiem).

Secara umum menunjukkan bahwa pemberian ransum yang mengandung limbah ikan leubiem dapat menekan nilai konversi ransum, dan meningkatkan penyerapan zat makanan sehingga berakibat pada meningkatnya bobot badan akhir itik petelur. Bobot badan akhir itik petelur merupakan akumulasi hasil metabolisme. Hasil metabolisme didukung oleh banyaknya ransum yang dikonsumsi serta optimalisasi penggunaan ransum. Dimana pemberian ransum yang mengandung limbah ikan leubiem berpengaruh nyata $(\mathrm{p}<0,05)$ terhadap bobot badan akhir itik petelur umur 29 minggu. Hasil uji lanjut menunjukkan bahwa bobot badan akhir itik petelur yang diberi ransum mengandung limbah ikan leubiem berbeda nyata $(p<0,05)$ dengan perlakuan ransum kontrol (R0). Rataan bobot badan akhir itik petelur tertinggi dicapai pada perlakuan ransum yang mengandung tepung kulit ikan leubiem (R1) yaitu 2309 g/ekor dan terendah diperoleh pada perlakuan ransum kontrol (R0) yaitu 2228 g/ekor (Tabel 3).

Hasil penelitian menunjukkan bahwa penggunaan tepung limbah ikan leubiem dalam formulasi ransum cenderung meningkatkan konsumsi ransum itik petelur (Tabel 3). Hal ini sesuai dengan hasil penelitian [7] yang menyatakan bahwa konsumsi ransum itik lebih banyak pada itik yang mendapatkan ransum dengan kandungan tepung ikan dan kadar protein yang lebih tinggi (23\%). Konsumsi ransum juga dipengaruhi oleh tingkat kecernaan protein, dimana kandungan protein yang terdapat dalam ransum menentukan sedikit banyaknya protein yang tercerna terutama asam amino esensial yang dibutuhkan ternak seperti lysin dan methionin sehingga diduga dapat meningkatkan nafsu makan [8]. Substitusi asam amino lysin, metionin dan triptopan cenderung meningkatkan konsumsi ransum pada ayam ras meskipun tidak nyata [9].

Selain itu konsumsi ransum pada ternak itik juga dipengaruhi oleh jenis galur itik, seperti pernyataan [10], bahwa itik Alabio memiliki konsumsi yang lebih tinggi dibandingkan dengan itik Cihateup. Tingkat konsumsi ransum juga dipengaruhi oleh keadaan lingkungan, serta temperatur lingkungan [11]. Selain faktor lingkungan seperti kesehatan, kualitas ransum, suhu, sistem pemberian ransum serta sifat genetik juga dapat memengaruhi konsumsi ransum ternak itik [12]. Faktor lain yang memengaruhi asupan ransum oleh ternak adalah palatabilitas (warna, rasa, bau, dan tekstur) [13].

Selanjutnya respons pertambahan bobot badan itik petelur dengan pemberian ransum yang mengandung limbah ikan leubiem (tepung kulit, kepala dan tulang) cenderung meningkat, kecuali pada perlakuan ransum yang mengandung tepung insang cenderung menurun (Tabel 3). Menurunnya pertambahan bobot badan ini diduga terkait dengan proses pencernaan dan penyerapan unsur nutrien oleh ternak itik tersebut. Penyerapan unsur nutrien yang rendah dari ransum menyebabkan pertambahan bobot 
badan itik menjadi menurun. Hasil ini sejalan dengan pendapat peneliti sebelumnya yang melaporkan bahwa sifat karakteristik pakan dan status fisiologis sistem pencernaan ternak dapat mengakibatkan kecernaan nutrien tersebut menjadi rendah [14].

Kemampuan seekor ternak untuk merubah zat nutrisi yang terdapat dalam ransum menjadi daging ditunjukkan dengan pertambahan bobot badan ternak tersebut. Menurut [15] laju pertumbuhan ternak ditunjukkan oleh pertambahan bobot badan. Pertambahan bobot badan sangat erat kaitannya dengan konsumsi ransum, karena konsumsi ransum menentukan masukan zat nutrisi kedalam tubuh yang selanjutnya dipakai untuk pertumbuhan dan keperluan lainnya. Jika fungsi fisiologis ternak tidak terganggu maka ransum yang dikonsumsi akan digunakan sebaik-baiknya untuk pertumbuhan [16].

Pemanfaatan ransum yang efisien pada unggas tidak hanya dilihat dari aspek pertambahan bobot badan, akan tetapi juga harus dilihat dari efisiensi penggunaan tingkat protein dan energi dalam ransum untuk menghasilkan pertumbuhan atau produktivitas ternak yang maksimal serta nilai konversi ransum. Konversi ransum sebagai tolak ukur untuk menilai seberapa banyak ransum yang dikonsumsi untuk menghasilkan bobot badan. Semakin kecil angka konversi ransum menunjukkan semakin efisiensi dalam penggunaan ransum. Beberapa faktor yang memengaruhi konversi ransum diantaranya adalah bentuk fisik pakan, kandungan nutrisi pakan, lingkungan tempat pemeliharaan, strain, bobot badan dan jenis kelamin serta kesehatan ternak. Selain itu konversi ransum juga dipengaruhi oleh jenis dan komposisi tepung limbah ikan yang digunakan dalam formulasi ransum itik petelur. Berdasarkan hasil penelitian [7] melaporkan bahwa komposisi tepung ikan dalam ransum berpengaruh terhadap nilai konversi ransum yang dihasilkan. Demikian juga hasil penelitian [3] melaporkan bahwa penggunaan kombinasi limbah ikan leubiem (kulit, kepala dan tulang) sebanyak 10\% dalam formulasi ransum dapat menurunkan konversi ransum itik lokal jantan umur 16 minggu.
Secara keseluruhan hasil penelitian ini mengindikasikan bahwa pemberian ransum yang mengandung limbah ikan leubiem dapat meningkatkan efisiensi penggunaan ransum pada itik petelur umur 21-29 minggu. Penggunaan limbah ikan leubiem dalam ransum diduga dapat mengoptimalkan fungsi metabolisme bahan makanan lainnya sehingga dapat meningkatkan efisiensi penggunaan ransum. Pemberian ransum yang mengandung limbah ikan leubiem menyebabkan ransum yang dikonsumsi lebih efisien, tetapi penyerapannya meningkat dan menghasilkan bobot badan lebih tinggi.

Kualitas ransum yang diberikan akan memengaruhi pertumbuhan ternak. Nutrien yang terserap sempurna dalam tubuh akan meningkatkan konsumsi pakan ternak sehingga pertumbuhan dan produksi akan semakin baik [4]. Hal ini sejalan dengan bobot badan akhir itik petelur yang dicapai pada akhir penelitian (umur 29 minggu) dimana bobot badan akhir itik petelur tertinggi dicapai pada perlakuan ransum yang mengandung tepung kulit dan kepala ikan leubiem (R1 dan R2) yaitu 2309 dan 2303 g/ekor, dan lebih tinggi $(\mathrm{p}<0,05)$ dibanding dengan perlakuan kontrol (R0) dan perlakuan ransum yang mengandung tepung insang ikan leubiem (R4), namun tidak berbeda nyata dibanding perlakuan ransum yang mengandung tepung tulang ikan leubiem (R3) (Tabel 3). Pemberian ransum yang mengandung limbah ikan leubiem (tepung kulit, kepala dan tulang) yang dihasilkan pada penelitian ini memberi indikasi bahwa limbah ikan leubiem sangat berpotensi digunakan sebagai salah satu bahan pakan sumber protein dalam formulasi ransum itik petelur umur 21-29 minggu.

\section{Produksi telur fase pertama}

Hasil analisis statistik menunjukkan bahwa penggunaan tepung limbah ikan leubiem (kulit, kepala, tulang dan insang) dalam formulasi ransum itik petelur tidak berpengaruh nyata terhadap umur bertelur pertama. Fase bertelur pertama berkisar antara umur 22,4 - 22,9 minggu (Tabel 4). Meskipun tidak menunjukkan perbedaan yang nyata, namun secara numerik umur bertelur pertama pada perlakuan ransum 
yang mengandung limbah ikan leubiem cenderung lebih produktif, karena umur bertelur pertama lebih cepat $(22,4-22,8$ minggu) dibandingkan dengan perlakuan kontrol (R0) yaitu umur 22,9 minggu.

Keadaan ini menjelaskan bahwa pencapaian umur bertelur pertama dapat dipengaruhi oleh konsumsi ransum dan bobot badan. Salah satu faktor yang memengaruhi umur bertelur pertama yaitu bobot badan. Bobot badan yang optimal dapat mempercepat umur bertelur pertama semakin cepat. Pemberian ransum yang mengandung limbah ikan leubiem memberi pengaruh yang nyata $(p<0,05)$ terhadap bobot badan bertelur pertama. Bobot badan tertinggi terdapat pada perlakuan ransum basal mengandung tepung insang dan tulang ikan leubiem yaitu 1620 dan 1615 g/ekor dan berbeda nyata $(p<0,05)$ dibanding dengan perlakuan ransum kontrol (R0) dan perlakuan ransum basal mengandung tepung kulit ikan leubiem (R1) yaitu 1576 dan $1590 \mathrm{~g} /$ ekor (Tabel 4).

Selanjutnya pemberian ransum yang mengandung limbah ikan leubiem pada itik petelur tidak memberi pengaruh yang nyata terhadap bobot telur pertama. Namun demikian Tabel 4 menunjukkan bahwa bobot telur pertama itik yang diberi ransum mengandung limbah ikan leubiem cenderung lebih tinggi dibanding perlakuan kontrol (R0). Bobot telur pertama yang dihasilkan berkisar antara 60,80 - 60,90 g/butir. Berbeda dengan produksi telur seperti yang ditampilkan pada Tabel 4. Pemberian ransum yang mengandung limbah ikan leubiem memberi pengaruh yang nyata $(p<0,05)$ terhadap produksi telur. Jumlah rataan produksi telur yang dihasilkan berkisar antara 27,23 $30,64 \% /$ minggu. Produksi telur tertinggi diperoleh pada perlakuan ransum mengandung tepung insang dan tulang ikan leubiem (R4 dan R3) yaitu 30,64 dan $29,69 \% /$ minggu dan lebih tinggi $(\mathrm{p}<0,05)$ dibanding dengan perlakuan kontrol (R0) yaitu $27,23 \% /$ minggu, dan perlakuan ransum yang mengandung tepung kulit ikan leubiem (R1) yaitu 28,83\%/minggu, namun tidak berbeda nyata dengan perlakuan ransum yang mengandung tepung kepala ikan leubiem (R2) yaitu 29,21\%/minggu (Tabel 4).

Berikutnya hasil analisis statistik terhadap indeks bentuk telur tidak menunjukkan perbedaan yang nyata dengan pemberian ransum yang mengandung limbah ikan leubiem. Indeks bentuk telur diperoleh dari perbandingan antara lebar telur dengan panjang telur dan dinyatakan dalam persen. Rataan indek bentuk telur yang dihasilkan pada penelitian ini berkisar antara 92,66 - 94,32\% bulat, 83,88 - 84,67\% normal, dan 75,49 $76,03 \%$ lonjong (Tabel 4).

Tabel 4. Produksi telur fase pertama

\begin{tabular}{lccccc}
\hline \multirow{2}{*}{ Variabel } & \multicolumn{5}{c}{ Perlakuan Ransum } \\
\cline { 2 - 6 } & R0 & R1 & R2 & R3 & R4 \\
\hline $\begin{array}{l}\text { Umur pertama bertelur } \\
\text { (minggu) }\end{array}$ & $22,9 \pm 2,2$ & $22,8 \pm 7.9$ & $22,6 \pm 8.0$ & $22,5 \pm 6.7$ & $22,4 \pm 7.3$ \\
$\begin{array}{l}\text { Bobot badan pertama } \\
\text { bertelur (g/ekor) }\end{array}$ & $1.576 \pm 11,2^{\mathrm{a}}$ & $1.590 \pm 62,7^{\mathrm{a}}$ & $1.603 \pm 77,6^{\mathrm{ab}}$ & $1.615 \pm 72,6^{\mathrm{b}}$ & $1.620 \pm 10^{\mathrm{b}}$ \\
Bobot telur pertama (g/butir) & $60,80 \pm 1,4$ & $60,86 \pm 1,34$ & $60,90 \pm 1,23$ & $60,85 \pm 1,8$ & $60,87 \pm 1,54$ \\
$\begin{array}{l}\text { Produksi telur (\%/minggu) } \\
\text { Indeks bentuk telur }\end{array}$ & $27,23 \pm 2,1^{\mathrm{a}}$ & $28,83 \pm 5,6^{\mathrm{a}}$ & $29,21 \pm 4,8^{\mathrm{ab}}$ & $29,69 \pm 4,1^{\mathrm{b}}$ & $30,64 \pm 4,5^{\mathrm{b}}$ \\
$\quad$ & & & & \\
$\quad$ Lonjong (\%) & $75,49 \pm 1,5$ & $75,56 \pm 2,5$ & $75,89 \pm 1.9$ & $76,03 \pm 3,4$ & $75,78 \pm 2,6$ \\
$\quad \begin{array}{l}\text { Normal (\%) } \\
\text { Bulat (\%) }\end{array}$ & $83,89 \pm 2,9$ & $83,88 \pm 3,4$ & $84,21 \pm 1,8$ & $84,34 \pm 2,7$ & $84,67 \pm 2,9$ \\
\hline
\end{tabular}

Keterangan : ${ }^{a, b, c}$ superskrip yang berbeda pada baris yang sama menunjukkan perbedaan yang nyata $(p<0,05)$; $\mathrm{R} 0$ = ransum kontrol (tanpa limbah ikan leubiem); R1 = ransum basal mengandung 10\% kulit ikan leubiem; R2 = ransum basal mengandung 10\% kepala ikan leubiem; R3 = ransum basal mengandung 10\% tulang ikan leubiem; R4 = ransum basal mengandung 10\% insang ikan leubiem 
Ternak itik mulai berproduksi telur fase pertama pada penelitian ini yaitu pada umur 22,4 - 22,9 minggu (Tabel 4). Umur pertama bertelur merupakan umur saat itik betina bertelur pertama yang menandakan telah mencapai dewasa kelamin dan dewasa tubuh. Ternak unggas akan mencapai dewasa kelamin jika telah mencapai bobot badan optimal [17]. Ternak itik akan mulai bertelur setelah mencapai bobot badan yang tepat [18] dan menurut [19] umur pertama bertelur ternak unggas sangat bervariasi tergantung pada manajemen pemeliharaan, pemberian ransum dan variasi individu.

Salah satu faktor yang memengaruhi umur pertama bertelur pada itik adalah bobot badan. Bobot badan merupakan salah satu sifat kuantitatif yang diwariskan namun penampakannya dipengaruhi oleh faktor lingkungan [11]. Bobot badan induk yang tinggi dapat menghasilkan produksi telur yang tinggi, serta dapat meningkatkan kualitas bibit yang dihasilkan [20]. Perbedaan bobot badan induk berpengaruh pada bobot telur yang dihasilkan, sehingga semakin beragam bobot induk yang berada pada satu kelompok itik, semakin beragam juga bobot telur yang dihasilkan. Umumnya masa percepatan pertumbuhan terjadi sebelum ternak mengalami dewasa kelamin, kemudian setelah dewasa kelamin terjadi perlambatan pertumbuhan [17].

Pemberian ransum yang mengandung limbah ikan leubiem tidak menunjukkan pengaruh yang nyata terhadap bobot telur pertama. Bobot telur pertama yang dihasilkan pada penelitian ini berkisar antara 60,80 $60,90 \mathrm{~g} /$ butir, dan lebih rendah jika dibandingkan dengan beberapa hasil penelitian sebelumnya. Sebagaimana [21] melaporkan bahwa rataan bobot telur itik Talang Benih selama fase produksi pertama (48 minggu) adalah 61,68 g/butir dan bobot telur itik Tegal, itik Pengging dan itik Magelang rata-rata 61,83; 63,66 dan 72,5 g/butir [22]. Faktor yang memengaruhi bobot telur diantaranya adalah besarnya kandungan protein dalam ransum yang dikonsumsi. Masing-masing ransum perlakuan mempunyai kandungan protein yang relatif sama, sehingga bobot telur yang diahasilkan juga relatif sama diantara perlakuan.
Kualitas pakan yang baik dalam hal ini kandungan protein, asam amino dan asam linoleat akan memengaruhi bobot telur, karena pakan dengan kualitas yang baik akan menghasilkan telur yang besar. Peningkatan bobot telur dapat terjadi karena kandungan asam amino dalam ransum sesuai dengan kebutuhan. Selain itu faktor yang berpengaruh pada bobot telur adalah genetis, umur induk itik, jenis itik, perubahan musim waktu bertelur, sifat keturunan, umur pembuahan, bobot badan induk dan pakan yang diberikan [23].

Menurut [22] bobot telur dipengaruhi besar kecilnya ukuran kuning telur. Bobot kuning telur dipengaruhi oleh perkembangan ovarium, bobot badan induk, dan umur dewasa kelamin. Selanjutnya [24] menyatakan bahwa ketersediaan dan kecukupan protein dan asam amino yang baik dapat meningkatkan bobot telur. Bobot telur juga dapat dipengaruhi oleh produksi telur yang terkait dengan kematangan sistem reproduksi, pemeliharaan, lingkungan dan kesehatan ternak.

Produksi telur itik yang diperoleh pada penelitian ini lebih rendah dibandingkan dengan penelitian lainnya, hal ini disebabkan oleh faktor umur itik yang digunakan, jenis itik dan juga pengaruh lingkungan. Dimana produksi telur itik pada penelitian ini belum mencapai masa puncak produksi sehingga produksi telur yang dihasilkan belum begitu maksimal. Produksi telur itik sangat dipengaruhi oleh konsumsi ransum dan kandungan nutrisi ransum. Konsumsi dan kandungan nutrisi ransum yang sama mengakibatkan produksi telur yang sama. Hal ini berkaitan dengan asupan energi dan protein, dimana keduanya menyumbang peran yang cukup besar dalam produksi telur.

Secara umum rata-rata produksi telur itik pada masa puncak produksi yang dipelihara secara intensif dapat mencapai 68,08\% [25], itik mojosari 63,18 - 68,68\%, dan itik Alabio $60,44-68,68 \%$. Rata-rata produksi telur itik lokal $56,21 \%$ dan puncak produksi telur itik lokal berkisar antara 54,17 - 65,03\% [26]. Selanjutnya pemberian ransum yang mengandung limbah ikan leubiem pada itik petelur juga berhubungan dengan indeks bentuk telur yang dihasilkan. Indeks bentuk 
telur digunakan untuk mengetahui bentuk telur yang baik. Indeks telur yang seragam akan memudahkan dalam penanganan dan pemasaran telur, serta memudahkan dalam memasukkan ke dalam kemasan. Indeks bentuk telur yang dihasilkan pada penelitian ini rata-rata berbentuk lonjong $75,49-76,03 \%$, normal $83,88-84,67 \%$ dan bulat $92,66-94,32 \%$. Berbeda dengan hasil penelitian [27] indeks bentuk telur yang dihasilkan yaitu 68,78$78,93 \%$ bentuk lonjong, $78,94-86,45 \%$ normal dan $86,46-98,59 \%$ bulat.

Nilai indeks bentuk telur yang berbeda dipengaruhi oleh beberapa faktor antara lain bangsa, genetik, umur, periode produksi, umur dewasa kelamin, saluran reproduksi, dan kualitas pakan [28]. Induk itik dengan umur dewasa kelamin lebih cepat memungkinkan saluran reproduksi bekerja lebih cepat berkembang seperti ukuran istmus yang semakin besar dan lebar sehingga akan menghasilkan indeks bentuk telur yang lebih besar. Periode awal indeks bentuk telur akan terlihat kecil dan masuk akhir periode bertelur indeks bentuk telur terlihat lebih besar. Pembentukan telur akan meningkatkan bentuk dan beratnya selama periode produksi sementara ketebalan dan kekuatan kulit telur biasanya menurun. Kekuatan dan ketebalan cangkang sangat berkorelasi satu sama lain serta bentuk indeks telur memiliki pengaruh terhadap proporsi albumen dan yolk [29].

Kesiapan saluran reproduksi memengaruhi hasil indeks bentukan telur lonjong, normal dan bulat. Indeks bentuk telur dipengaruhi oleh saluran reproduksi dan dapat berkembang karena adanya perubahan pada daerah magnum, istmus dan uterus (organ pembentukan telur). Demikian juga pakan sangat berpengaruh terhadap bobot telur, karena pakan yang kandungan nutriennya seimbang dan jumlahnya sesuai dengan kebutuhan itik akan menghasilkan bobot telur yang standar [30]. Bobot dan ukuran telur juga dapat dipengaruhi oleh tingkat protein dalam ransum. Ransum dengan protein rendah akan menyebabkan pembentukan kuning telur yang kecil sehingga telur yang dihasilkan juga akan kecil dan demikian sebaliknya [24].

\section{KESIMPULAN}

Penggunaan limbah ikan leubiem (kulit, kepala, tulang dan insang) dalam formulasi ransum tidak memberi efek negatif terhadap produktivitas itik petelur, dan sangat berpotensi digunakan sebagai salah satu bahan penyusun ransum sumber protein dalam formulasi ransum itik petelur umur 2129 minggu.

\section{KONFLIK KEPENTINGAN}

Para penulis menyatakan tidak ada konflik kepentingan keuangan atau hubungan dengan orang atau organisasi yang dapat secara tidak wajar memengaruhi atau menimbulkan bias pada isi yang dibahas dalam naskah artikel ini.

\section{UCAPAN TERIMA KASIH}

Terima kasih penulis sampaikan kepada Direktorat Riset dan Pengabdian Masyarakat, Direktorat Jenderal Penguatan Riset dan Pengembangan, Kementerian Riset, Teknologi, dan Pendidikan Tinggi yang telah memberikan dukungan dana dalam penelitian ini. Laboratorium Lapangan Peternakan, Prodi Peternakan Fakultas Pertanian, Universitas Syiah Kuala yang telah menyediakan fasilitas dan memberi dukungan selama pelaksanaan penelitian.

\section{DAFTAR PUSTAKA}

1. Shandu, S. T. 2014. Duck Health Care, Duck Research Laboratory. Comel University of veterinary Medicine. Ithaca York.

2. Yunitasari, F, L. D. Mahfudz, dan I. Mangisah. 2018. Pengaruh Penggunaan Limbah Cair Pemindangan Ikan dalam Ransum terhadap Efisiensi Penggunaan Protein Itik Persilangan Mojosari Peking Fase Pertumbuhan. Jurnal Sain Peternakan Indonesia. 13 (4): 412-419. https://doi. org/10.31186/jspi.id.13.4.412-419.

3. Daud, M., Fuadi, Z. dan Mulyadi. 2020. Performan dan produksi karkas itik lokal 
dengan pemberian ransum yang mengandung limbah ikan leubim (Canthidermis maculata). Jurnal Agripet. 20(1):9-16. https://doi.org/10.24815/agripet. v20i1.15149.

4. Daud, M., Yaman, M, A., Zulfan, and Asril, 2020. Effects of probiotic supplementation in rations containing leubim fish waste (Canthidermis maculata) on the performance of local ducks. IOP Conf. Series: Earth and Environmental Science 425 (2020) 012003. doi:10.1088/17551315/425/1/012003.

5. SNI. 2019: Feed the laying ducks. SNI 8821:2019. Badan Standarisasi Nasional. Jakarta.

6. Steel, R. G. D. and J. H. Torrie. 1995. Principle and Procedures of Statistics. McGraw Hill Book Inc. New York.

7. Purba, M. dan Prasetyo L. H. 2014. Respon pertumbuhan dan produksi karkas itik pedaging EPMP terhadap perbedaan kandungan serat kasar dan protein dalam pakan. Jurnal Ilmu Ternak dan Veteriner. 19 (3): 220-230. http://dx.doi.org/10.14334/ jitv.v19i3.1085.

8. Kong, C. and O. Adeola. 2013. Additivity of amino acid digestibility in corn and soybean meal for broiler chickens and White Pekin ducks. Poultry Science 92 :2381-2388. http://dx.doi.org/10.3382/ps. $2013-03179$.

9. Fenita, Y., Santoso, U. dan Prakoso, H. 2010. Pengaruh suplementasi asam amino lisin, metionin, tritopan dalam ransum berbasis lumpur sawit fermentasi terhadap performans produksi dan kualitas telur ayam ras. Jurnal Sain Peternakan Indonesia. 5(2): 105-114. https://doi.org/ 10.31186/jspi.id.5.2.105-114.

10. Suryana. 2013. Pemanfaatan keragaman genetik untuk meningkatkan produktivitas itik alabio. J. Litbang Pert. 32 (3): 100-111. http://dx.doi.org/10.21082/jp3. v32n3.2013.

11. Daud, M., Fuadi, Z. dan Mulyadi, 2017. Performa dan persentase karkas ayam ras petelur jantan pada kepadatan kandang yang berbeda. Jurnal Agripet. 17(1): 6774. https://doi.org/10.17969/agripet.v17i1. 7557.

12. Ismoyowati., Indrasanti, D. and Sulistyawan, I. H., 2018. The Differences of
Feed Quality and Egg Production Performance of Tegal and Magelang Ducks on Farming in Central Java. Buletin Peternakan. 42(3): 197-202. DOI: 10.21059/ buletinpeternak. v42i3.34465.

13.Sjofjan, O., E. Widodo, Halim N, Fatmaoctavia S, and Riany G. S. 2019. Effect of Prebiotic and Immunowall ${ }^{\circledR}$ as Feed Additive in Enzyme Activity, Intestinal Characteristic, and Broiler Performance. International Journal of Food Science and Agriculture, 3(4), 292-298. DOI: 10.26855/ijfsa.2019.12.005.

14. Wei Fen Li, Imran Rashid Rajput, Xin Xu, Ya Li Li, Jian Lei, Qin Huang and Min Qi Wang. 2011. Effects of Probiotic (Bacillus subtilis) on Laying Performance, Blood Biochemical Properties and Intestinal Microflora of Shaoxing Duck. International Journal of Poultry Science 10 (8): 583-589.

15. Budiansyah. A, Resmi, Filawati, and U. Haroen. 2020. Performance of Kerinci ducks treated by cattle rumen-fluid supernatant addition as source of crude enzyme in rations. Tropical Animal Science Journal, 43(2):125-132. https://doi.org/ 10.5398/tasj.2020.43.2.125.

16. Daud, M., Mulyadi. and Fuadi, Z., 2016. Persentase karkas itik peking yang diberi pakan dalam bentuk wafer ransum komplit mengandung limbah kopi. Jurnal Agripet. 16(1): 62-68. http://dx.doi.org/ 10.17969/agripet.v16i1.3837.

17. Swiatkiewicz, S., J. Koreleski, and A. Arczewska. 2010. Laying performance and eggshell quality in laying hens fed diets supplemented with prebiotics and organic acids. Czech J. Anim. Sci. 55:294-306. https://doi.org/10.17221/207/2009-CJAS.

18. Nurrofingah. U, Sumiati, and Y. Retnani. 2020. Evaluation of Sweet Potato Leaves and Cassava Leaves Inclusions into the Diet Containing Lemuru Oil on Lipid Metabolism in Local Duck. Tropical Animal Science Journal. 43(2):141-150. https://doi.org/10.5398/tasj.2020.43.2.141.

19. Cao, Z., B. Meng, R. Fan, M. Liu. M.Gao, Z. Xing, and X. Luan. 2018.Comparative proteomic analysis of ovaries from Huoyan geese betweenpre-laying and laying periods using an iTRAQ-based approach. Poult.Sci.97:2170-2182. http://dx.doi.org/ 
10.3382/ps/pey029.

20. Rattanawuta, J, D. Trairabeapa, S. J. Karrilaa, P. Rodjanb, and Y. Theapparatc. 2019. Production Performance, Egg Quality, and Fecal Bacterial Population of Laying Ducks Fed Ration Supplemented by Bamboo Vinegar. Tropical Animal Science Journal 42(3):224-229. https:// doi.org/10.5398/tasj.2019.42.3.224.

21. Kususiyah dan Kaharuddin. 2008. Performans pertumbuhan itik Talang benih jantan dan betina yang dipelihara secara intensif. Jurnal Sains Peternakan Indonesia. 3(2): 49-54. https://doi.org/ 10.31186/jspi.id.3.2.49-54.

22. Purwati, D., M. A. Djaelani, dan E. Y. W. Yuniwarti. 2015. Indeks kuning telur (IKT), haugh unit (HU) dan bobot telur pada berbagai itik lokal di Jawa Tengah. Jurnal Biologi 4(2): 1-9.

23. Wolc, A. Arango J, Settar P, O'Sullivan NP, Olori VE, White IMS, Hill WG, Dekkers JCM. 2012. Genetic parameters of egg defects and egg quality in layer chickens. Poult Sci. 91(6):1292-1298. https://doi.org/ 10.3382/ps.2011-02130.

24. Sumiati, and Piliang W. G. 2005. Increasing laying performance and egg vitamin A content through zinc oxide and phytase enzyme supplementation. Media Peternakan. 28(3):130-135.

25. Loing, J., B. Setiawan, M. Wahib, R. Anindhita, dan E, Lengkong. 2015. Increasing duck egg productionusing grow enhancer treatment. International Journal of Biosciences 6(3): 31-35. http://dx.doi.org/ 10.12692/ijb/6.3.31-35.
26. Maskur, S. Prasetyo, Lestari, R. Jan, T. Rozi, dan L.M. Kasip. 2018. Produksi dan kualitas telur itik lokal lombok untuk bahan telur asin yang dipelihara peternak secara intensif di lombok tengah. Jurnal Ilmu dan Teknologi Peternakan Indonesia 4 (1):199-206. https://doi.org/10.29303/jitpi. v3i1.31.

27. Suselowati, T., E. Kurnianto, dan S, Kismiati. 2019. Hubungan indeks bentuk telur dan surface area telur terhadap bobot telur, bobot tetas, persentase bobot tetas, daya tetas dan mortalitas embrio pada itik pengging. Sains Peternakan 17(2):24-30. http://dx.doi.org/10.20961/sainspet.v\%vi\% i. 30212 .

28. Sumiati, A. Darmawan, and K. G. Wiryawan. 2016. Egg quality and blood hematology of magelang laying duck fed with diets containing different ratios of omega 3 and omega 6 fatty acids and organic Zn. Int. J. Poult. Sci. 15:448-453. https://doi.org/10.3923/ijps.2016.448.453.

29. Haryanto, A.N, W. Sarengat, dan D. Sunarti. 2019. Kualitas fisik telur itik tegal yang dipelihara menggunakan sistem pemeliharaan intensif dan semi intensif di KTT Bulusari Kabupaten Pemalang. Sains Peternakan. 17(1):29-37. https://doi.org/ 10.20961/sainspet.v17i1.25984.

30. Ketaren, P. P. dan L. H. Prasetyo. 2002. Pengaruh pemberian pakan terbatas terhadap produktivitas itik silang Mojosari $x$ Alabio (Ma): 1. Masa bertelur fase pertama umur 20-43 minggu. Jurnal Ilmu Ternak dan Veteriner 7(1): 38-45. 